\section{Humane Herpes-7-Viren}

\author{
W. Stöcker \\ Euroimmun Medizinische Labordiagnostika AG, Lübeck, \\ Deutschland
}

Englischer Begriff Human herpes virus type 7

Beschreibung des Erregers Das humane Herpes-Virus 7, erstmals im Jahr 1990 beschrieben, repliziert sich in CD4 ${ }^{+}-\mathrm{T}-$ Lymphozyten und persistiert in Epithelzellen der Mundspeicheldrüsen. HHV-7 gehört zur Familie Herpesviridae (behüllte Viren mit einer doppelsträngigen, linearen DNA als Genom), Unterfamilie $\beta$-Herpesvirinae. Die HHV-7Virionen (Durchmesser $170 \mathrm{~nm}$ ) bestehen aus einem ikosaedrischen Kapsid, das von Tegumentproteinen umkleidet und von einer äußeren Virushülle umgeben ist. Reservoir für HHV-7 ist ausschließlich der infizierte Mensch. Das Virus vermehrt sich in Speicheldrüsenepithelien und wird in den Speichel abgegeben.

Erkrankungen HHV-7 wird als mögliche Ursache einer Reihe verschiedener Krankheiten angesehen. Darunter sind unspezifische fieberhafte Viruserkrankungen mit Exanthem, in seltenen Fällen mit neurologischer Symptomatik, wie Fazialisparese, Meningitis und Krampfanfälle. Darüber hinaus wurde ein Zusammenhang zu Pityriasis rosea beschrieben. In seltenen Fällen kann sich auch das Bild eines Exanthema subitum zeigen ( $>$ Humane Herpes-6-Viren).

Die Primärinfektion findet im Säuglings- bis Kleinkindalter statt (später als die HHV-6-Infektionen), bei Erwachsenen beträgt die Prävalenz 95 \%. Behandlung der Primärinfektion allenfalls symptomatisch. Ganciclovir zeigt gegenüber HHV7, im Gegensatz zu HHV-6, eine schlechte Wirksamkeit und wird nicht zur Therapie empfohlen.
Analytik Direktnachweis: Viruskultur oder Nachweis viraler DNA durch Virussubtyp-spezifische PCR ( $\$$ PCR (Polymerase-Kettenreaktion)).

Serologie: Antikörperbestimmung durch einen $>$ Enzymimmunoassay. Im Wesentlichen sind ELISA-Verfahren ( $\triangleright$ Enzyme-linked Immunosorbent Assay) beschrieben, deren Antigene aus Viruskulturen gewonnen werden.

\section{Untersuchungsmaterial - Probenstabilität Direktnach-} weis: mittels PCR: Liquor.

Serologie: Serum oder Liquor. Patientenproben für Antikörper sind bei $+4{ }^{\circ} \mathrm{C}$ bis zu 2 Wochen lang beständig, bei $-20{ }^{\circ} \mathrm{C}$ über Monate und Jahre hinweg. Zur Tiefkühlkonservierung des IgM kann man den Proben 80 \% gepuffertes Glyzerin beifügen.

Diagnostische Wertigkeit Für HHV-7-Infektionen ist eine Labordiagnostik in der Regel nicht erforderlich. Die Viruskultur wird nur in Speziallaboren durchgeführt und ist diagnostisch unbedeutend. Bei Verdacht auf Enzephalitis besitzt die Virussubtyp-spezifische $>$ PCR (Polymerase-Kettenreaktion) mit Liquorproben die höchste Aussagekraft. Für den Antikörpernachweis ist insbesondere die Kreuzreaktivität mit CMV und HHV-6 zu beachten, da den $\beta$-Herpes-Viren viele Epitope gemeinsam sind.

\section{Literatur}

Frenkel N, Schirmer EC, Wyatt LS, Katsafanas G, Roffman E, Danovich RM, June CH (1990) Isolation of a new herpesvirus from human CD4+ T cells. Proc Natl Acad Sci U S A 87:748-752

Gärtner BC, Müller-Lantzsch N (2007) Dreitagefieber/Humanes Herpesvirus 6 und 7. In: Handbuch der Infektionskrankheiten, Hofmann, VIII-6.10, 18 